\title{
The Shi Epoxidation
}

\section{Category}

Organo- and

Biocatalysis

\section{Key words}

ketone catalysis

dioxiranes

fructose

Shi epoxidation

alkenes

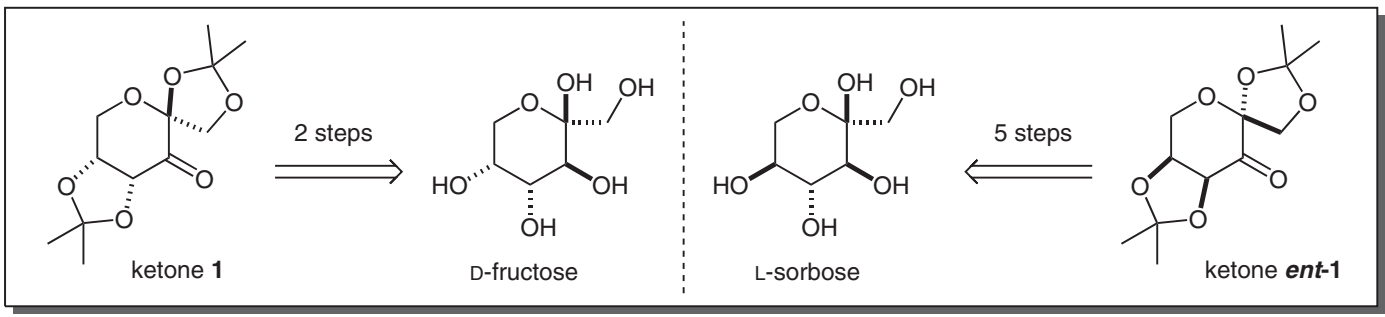

Proposed mechanism:

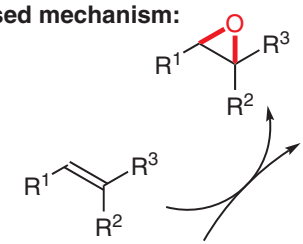<smiles>COC12OCC3OC(C)(C)OC3(OO1)C1OC(C)(C)OC1O2</smiles><smiles></smiles>

$$
\begin{gathered}
\text { ketone } 1(30 \text { mol\%) } \\
\text { Oxone }(1.38 \text { equiv) } \\
\mathrm{K}_{2} \mathrm{CO}_{3}(5.8 \text { equiv) } \\
\mathrm{Bu}_{4} \mathrm{NHSO}_{4} \text { (cat.) } \\
\underset{\mathrm{MeCN}-(\mathrm{DMM})-\mathrm{H}_{2} \mathrm{O}}{\text { borax } / \mathrm{Na}_{2} \text { (EDTA)-buffer }}
\end{gathered}
$$<smiles>[R7]C1OC1([R])[3H]</smiles>

yield up to $98 \%$ er up to $>99: 1$<smiles>CCOC(=O)C(C)C</smiles>

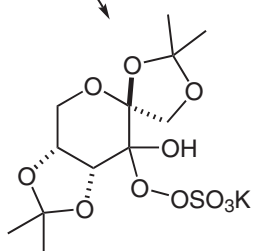

Transition-state model:

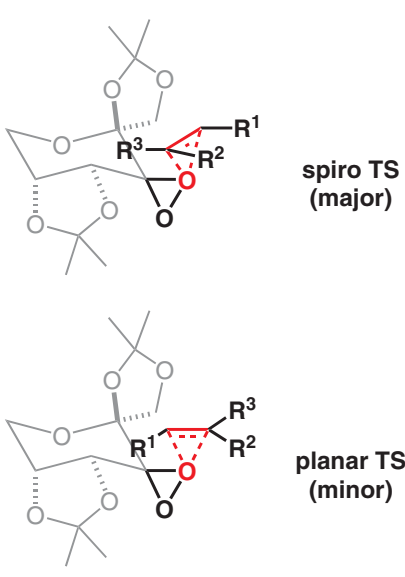

Significance: In the late 1990s, the research group of Shi developed the first general effective organic catalyst for the asymmetric epoxidation of nonactivated trans-olefins or trisubstituted olefins with potassium peroxomonosulfate (Oxone). Ketone $\mathbf{1}$ and its enantiomer ent-1 are readily available from the inexpensive carbohydrates D-fructose and L-sorbose, respectively. Even though terminal olefins and cis-olefins are due to the lack of steric repulsion in the transition state unsuitable substrates in the Shi epoxidation, the method has found wide application in organic synthesis.
Comment: Deliberate tuning of the $\mathrm{pH}$ is necessary for the reaction to proceed without substantial decomposition of the catalyst through a BaeyerVilliger oxidation. Thus, an elaborate solvent/buffer system (including metal salts) is required. However, in contrast to the Jacobsen or Sharpless methodologies, the Shi epoxidation does not use transition metals in its catalytic cycle. In addition, the authors developed a further variant that only requires hydrogen peroxide as the oxidant (Tetrahedron Lett. 1999, 40, 8721). 